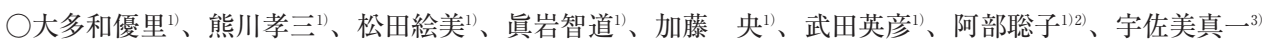
虎の門病院 耳鼻咽喉科 ${ }^{11}$ 、阿部耳鼻咽喉科 ${ }^{2)}$ 、信州大学 医学部 耳鼻咽喉科 ${ }^{3)}$

難聴の原因遺伝子は100種類以上あると考えられているが、保険収載された難聴遺伝子検査では高頻度の13遺伝子 46 変異 を検索している。この中でミトコンドリア遺伝子変異としては 3243A $>\mathrm{G}$ 変異、1555A $>\mathrm{G}$ 変異、7445A > G 変異、8296A> $\mathrm{G}$ 変異の 4 つがスクリーニング項目として採用されており、前者 2 つに関しては日本人難聴患者で多くの報告がある。今回 われわれは38歳の先天性高度難聴を呈する発端者の男性患者に難聴遺伝子検査を行ったところ、8296A $>\mathrm{G}$ ホモプラスミー を認めた症例を経験した。発端者は非症候性難聴を呈し、糖尿病、心電図異常、腎機能障害などは認められなかった。母に は難聴は認められなかった。 $8296 \mathrm{~A}>\mathrm{G}$ 変異に関しては糖尿病家系の報告は認めるが、難聴を発症する報告はまれである。 本家系においては妻も先天性高度難聴であったが、遺伝子変異は検出されなかった。 $8296 \mathrm{~A}>\mathrm{G}$ 変異の前庭機能を含めた内 耳病態、難聴の進行性、本夫婦の次世代難聴の発現率に関してのカウンセリングを中心に報告する。

\title{
159 当科における難聴遺伝カウンセリング外来の現況
}

○荒井康裕 ${ }^{1}$ 、高橋優宏 ${ }^{1}$ 、佐久間直子 ${ }^{1)}$ 、宇佐美真 - ${ }^{2}$ 、折舘伸彦 ${ }^{1)}$

横浜市立大学 医学部 耳鼻咽喉科・頭頸部外科 ${ }^{12}$ 、信州大学 医学部 耳鼻咽喉科 ${ }^{2}$

2012年 4 月より難聴遺伝子診断が保険適応となり、当院でも同年10月より遺伝子診療部の協力の元、難聴遺伝子診断およ び遺伝カウンセリングを開始した。2012年10月より2013年10月までに当科で難聴遺伝子解析および遺伝カウンセリングを施 行した難聴症例13家系20名を検討の対象とした。年齢分布は 1 歳 44歳で、18歳以下が15例、19歳以上が 5 例であった。 20 例中 5 例で難聴遺伝子変異をみとめた。変異の内訳は、GJB2 複合へテロ接合変異が 3 例、ホモ接合変異 1 例、SLC26A4 複 合へテロ接合変異 1 例であった。変異を認めた 5 例の内 3 例で遺伝カウンセリング後に人工内耳埋め込み術を施行した。ま た、13家系に対して遺伝カウンセリング後にアンケートを施行し検討を行った。

160 当センターにおける難聴遺伝子検査症例の検討

○石川浩太郎

国立障害者リハビリテーションセンター＼cjkstart病院耳鼻咽喉科

難聴遺伝子診断は全国で広く臨床応用されている。当センターではこれまで未実施であったが、平成25年 7 月 8 日に遺伝 子倫理審査が承認され、遺伝カウンセリング加算の施設承認も行った。11月末までにインベーダ法による健康保険検査と共 同研究両者の同意症例が 6 家系 19 人、共同研究検査のみを同意した症例 2 家系 2 人について遺伝子検査を施行した。また他 院で難聴遺伝子変異が同定され、詳細なカウンセリングを施行されていなかった 2 家系について、当センターで遺伝カウン セリングを行った。保険検查と研究の両者を施行したのは常染色体優性遺伝疑い 4 家系、常染色体劣性遺伝疑い 2 家系で、 研究検査のみはアッシャー症候群疑いの 2 例に施行した。11月末現在、保険検查 6 家系分の結果が到着し、劣性遺伝が疑わ れた姉妹で GJB2 遺伝子複合へテロが、優性遺伝が疑われた小览で GJB2 遺伝子 $235 \mathrm{delC}$ 変異へテロのみが同定された。こ の 2 家系と他施設で同定された GJB2 遺伝子 p. R143W 変異へテロのみ、SLC26A4 遺伝子複合へテロの 2 家系についてカウ ンセリングを行った。

161

\section{メニエール病患者における内リンパ腔サイズの変化}

○須賀研治、吉田忠雄、中田隆文、下野真理子、加藤正大、大竹宏直、加藤 健、寺西正明、轓根三千彦、 中島 務

名古屋大学 医学部 耳鼻咽喉科

（目的）当科ではメニエール病やその周辺疾患の内耳 Gd 造影 MRIによる内リンパ水腫の評価を行ってきた。今回われわ れはメニエール病患者に複数回 MRI 撮影を行い内リンパ腔サイズの経時的変化について評価したので報告する。（対象・方 法）対象は2011年 3 月から2013年 7 月までに当科受診したメニエール病13症例 26 耳。以下の項目を評価した。 1 患側・健側 耳 2 聴力評価（3 分法） 3 臨床診断（AAO-HNS の診断基準使用） 4 罹病期間 5 MRI 水腫評価（水腫なし、軽度、著明の 3 段階評価)。(結果) Definite MD では蝸牛・前庭水腫はすべての症例で認められた。13症例中 3 例で水腫サイズ変化認 め、罹病期間が 4 カ月以上の症例ではサイズ変化認められなかった。蝸牛水腫変化に関して患側耳著明水腫症例にサイズ変 化認め、健側耳でも水腫を認める症例が多い結果となった。前庭水腫変化に関して患側耳サイズ変化は 1 例のみ、健側耳水 腫は有意に少ない結果となった。(考察) 罹病期間の短い症例で内リンパ胿サイズ変化を認めた。前庭の内リンパ水腫変動 は少なかった。 


\section{MRI によるイソソルビド内リンパ水腫軽減勃果の検討}

○福岡久邦 ${ }^{122}$ 、工 穣 1 、岩佐陽一郎 ${ }^{1}$ 、吉村豪兼 ${ }^{12}$ 、塚田景大 ${ }^{1)}$ 、宇佐美真一 ${ }^{11}$

信州大学 医学部 耳鼻咽喉科学講座 ${ }^{11}$ 長野松代総合病院 ${ }^{2}$

メニエール病の病態は内リンパ水腫とされる。薬物治療として、利尿薬治療は日常診療で用いられて扔り、その中でも浸 透圧利尿薬であるイソソルビドが多用されておりその有効性について多くの報告がなされている。イソソルビドは、浸透圧 勾配により内リンパ腔からの水の移動により水腫が軽隇するとされ、動物実験では水腫の改善が確認されている。ただ、ヒ トでの直接的な確認は不可能であるため、これまでイソソルビドの効果判定には症状や内リンパ水腫推定検査により間接的 に評価せざるを得なかった。一方当教室では、これまでにガドリニウム鼓室投与後に 3T-MRI を施行し、メニエール病患 者で内リンパ水腫の画像診断を行いその有用性を報告してきた。また、昨年の本学会にて、3T-MRI を経時的に行うことで イソソルビドの内リンパ水腫軽減効果を画像的に評価し報告を行った。今回はさらに症例を増やし、評価方法も含め再検討 を行ったので報告する。(本研究は信州大学放射線科 角谷眞澄教授、同放射線部 上田仁技師との共同研究によって行わ れた）

\section{3 メニエール病患者の Dizziness Handicap Inventory (DHI) に関する検討}

○江上直也、岩崎真一、藤本千里、鴨頭 輝、木下 淳、牛尾宗貴、菅澤恵子、山岨達也 東京大学 医学部 耳鼻咽喉科

【背景】メニエール病患者はめまいを反復することで日常生活に支障を来し、めまい発作に対する不安や恐怖に悩まされ ることが多い。めまいの総合的な重症度を評価する尺度としてDHI(Dizziness Handicap Inventory) はめまい診療において 汎用されている。今回、われわれはメニエール病患者の DHIに関して他のめまい疾患と比較検討したので報告する。 【方法】2007年 1 月から 2013 年 6 月に当科めまい外来を受診し、メニエール病確実例と診断された112例（一側例：87例、両 側例 : 25例）を対象としてメニエール病の病期分類とDHI との相関を検討し、良性発作性頭位眩量症（BPPV）、前庭神経 炎、心因性めまい症例と比較した。【結果】メニエール病症例の DHI の平均值は一側例 40.6、両側例44. 3で、病期の進行し た群では DHI が有意に高い傾向を認めた。BPPV、前庭神経炎、心因性めまいはそれぞれ38.3、37.2、51.2であった。 【結論】メニエール病では病期が進むとめまいに対する不安等により DHI が高くなる傾向があると推測された。

\section{4 難治性内リンパ水腫疾患に対する鼓膜マッサージ機による中耳加圧療法}

○将積日出夫 ${ }^{1)}$ 、高倉大匡 ${ }^{1)}$ 、坪田雅仁 ${ }^{1)}$ 、石田正幸 ${ }^{1)}$ 、阿部秀晴1)、藤坂実千郎 ${ }^{1)}$ 、渡辺行雄 ${ }^{2}$ 富山大学 医学部 耳鼻咽䚐科 ${ }^{1)}$ 、大沢野老人保健施設かがやき2)

【目的】鼓膜マッサージ機は耳管処置の治療器として販売されている中耳加圧器であり、当科では富山大学倫理審査委員 会の承認の元、難治性内リンパ水腫疾患に対する治療法として Meniett ${ }^{\circledR}$ と同様に導入を行ってきた。今回は、鼓膜マッサ ージ機による中耳加圧療法の有用性について検討する。【方法】富山大学附属病院において保存的治療に抵抗してめまい発 作を反復する難治性内リンパ水腫疾患に対して 2007 年から鼓膜マッサージ機により中耳加圧療法を行い、12力月以上経過観 察した26症例（メニエール病20例、遅発性内リンパ水腫 6 例）を対象として、治療開始12力月後（N=26）および24力月後 （N=18）にめまいおよび聴力に対する治療効果を評価した。【結果】治療開始12力月後、24力月後のいずれも治療前に比べ てめまい回数や重症度の軽減がみられた。一方、聴力は不変例が多数であった。【結論】難治性内リンパ水腫疾患に対して 鼓膜マッサージ機はめまい制御に有用な低侵襲な治療器具であると考えられた。

\section{5 メニエール病の姿勢制御・歩行機能に対する内リンパ裹手術の影響}

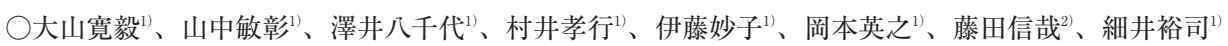
奈良県立医科大学 耳鼻咽喉頭頸部外科学講座 ${ }^{12}$ 、県立奈良病院 耳鼻咽喉科 ${ }^{2}$

【目的】内リンパ囊手術が適応とされる重症のメニエール病では姿勢保持や歩行に支障を来していることも多い。今回、 内リンパ囊開放術により体平衡機能がどのように影響を受けるかを検討した。

【方法】2007年から2012年に内リンパ囊開放術を施行し、体平衡機能を追跡できたメニエール病41例（男性21例、女性20 例、平均年齢59.2歳）を対象にした。術前と術後の間欠期に重心動摇速度と動的歩行機能評価（Functional Gait Assessment：FGA）スコア（10項目30点満点）を測定し比較検討した。

【成績】術後、重心動摇速度は減少する傾向にあった。ラバーなし・開眼条件下とラバーあり・閉眼条件下の動摇比率は、 異常値から正常值へ改善し、末梢前庭機能障害を反映する視覚・体性感覚依存率は低下した。一方、FGAに関しては個体 差が大きく、平均すると術前とほぼ変わらなかった。

【結論】メニエール病進行例にみられる体平衡障害の一部は、内リンパ水腫増大によって引き起こされている可能性があ り、内リンパ囊手術により可逆的であることが考えられる。 


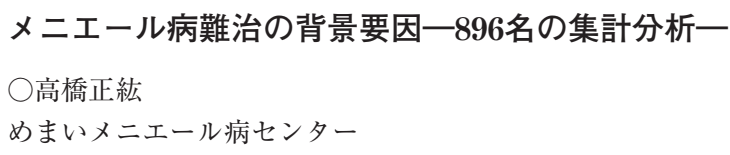

【目的】同一医師の診断、同一治療のメ病集計として稀有の896名（15.6\%）に達したので、メ病難治の背景を調べた。 【対象および方法】 7 年 6 力月間のメ病確実例、男性367名15 84歳、女性529名13〜90歳。データベースの項目一年齢、発 症年齢、職種、患耳、発症誘因、合併症、めまいと聴力予後一を集計分析し、進行の規則性、責任要因を探った。【結果】 発症年齢は30～50代に集中し、主婦、事務職、無職、現場作業、販売接客、営業職、教師で $78 \%$ 。発症誘因は男性で職場の 多忙、ストレス、女性で家庭内不和、トラブル、兼業多忙が多数を占めた。患耳は有意に左耳に多く、全音域 $40 \mathrm{~dB}$ 以上は 罹病期間対数に比例して増え、罹病 8 年で半数、両側障害は罹病16年で半数に達した。【考察と結論】メ病の難聴は一定確 率で進行し、一見、内耳不可逆性病態を思わせる。しかし、強い我慢、熱中行動、報われない職場や家庭環境が共通し、こ れらが発症、増悪要因であることを強く示唆する。早期にこの関係を断ち切れば、治癒も可能であり、示唆に富む症例を供 覧する。

\section{7 耳かきにより迷路気腫を来したアブミ骨脱臼症例}

○岡崎由利子、佐藤栄祐、中村紗矢香、佐野 罜、安藤 篤 中部労災病院 耳鼻咽喉科

【症例】23歳女性【主訴】めまい、右難聴【現病歴】20歳の夏に耳かきで誤って右耳を刺し受傷。直後から回転性めまい、 右鼓膜穿孔、難聴、耳鳴を認め、他院で迷路気腫を指摘された。保存的治療を施行され鼓膜穿孔は治癒したがめまいは完治 しなかった。約 3 年後当科を受診し、右壟、中内耳 CT で迷路気腫、アブミ骨脱臼を認めた。鼻をかむと増悪する回転性め まいを認めたため右試験的鼓室開放術を施行した。【手術所見】キヌタアブミ関節脱臼を認め、アブミ骨は内耳に落ち込ん でいた。卵円空は開存し、リンパ液の流出を認めた。アブミ骨を摘出し側頭筋膜で卵円空を被覆した。【術後経過】めまい は消失し、術後の中内耳 CT で迷路気腫の消失を確認した。【考察】めまいや難聴が続く迷路気腫は積極的な手術により改 善する可能性があると考える。

\section{8}

\section{当科における外リンパ瘻手術例の検討}

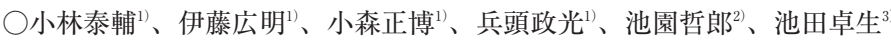
高知大学 医学部 耳鼻咽喉科 ${ }^{1}$ 、埼玉医科大学 医学部 耳鼻咽喉科 ${ }^{2}$ 、 鼓ケ浦こども医療福祉センター 耳鼻咽喷科 ${ }^{3)}$

外リンパ瘦の症候は多彩で術前診断、特に特発性外リンパ㿉の診断は困難で、たとえ試験的鼓室開放術を行っても、必ず しも外リンパの漏出を視認するのは容易でない。このことが本症の診断や治療に関する議論を阻んできた。近年、Ikezono らが外リンパに特異的タンパクである cochlin-tomoprotein (CTP) を同定し、この臨床応用が可能となり、再び外リンパ瘦 に関する議論が活発になってきた。当科においても2012年から外リンパ瘦が疑われる症例において CTPの測定を行ってい る。今回、当科に拈いて外リンパ瘦を疑って手術を行った症例の臨床的検討を行った。2010年 3 月から 2013 年 6 月の間にめ まい、耳閉感や難聴を主訴に当科を受診し、外リンパ瘦を疑って手術を行ったのは12例（男性10例、女性 2 例、年齢16〜 78 歳)、12耳であった。術中、9耳では明らかな外リンパの漏出所見はなかったが、全例で内耳空閉鎖を行った。これら症例 の臨床経過と術前、術後の眼振所見を中心に報告する。

\section{9 外リンパ瘻確定診断法一CTP 検査の生化学的信頼性一}

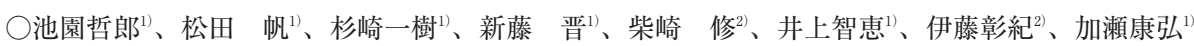
埼玉医科大学 医学部 耳鼻咽喉科 ${ }^{1)}$ 、埼玉医科大学 医学部 神経耳科 ${ }^{2}$

内耳リンパ腔と周囲臟器のあいだに瘻孔が生じ、生理機能が障害される疾患が外リンパ瘦である。瘦孔から外リンパが漏 出すると、さらに症状が増悪、変動する。今回、診断基準項目に「中耳から Cochlin-tomoprotein (CTP) が検出できた」が 加えられた。

CTP 陽性例の外リンパ瘦の症状、生理学的所見をみてみると、下記のような特徽があり、症状、生理学的検査所見から は確定診断が難しいことを示している。A突発的、または数日間の経過で発症する。B難聴、耳鳴、耳閉塞感、めまい、平 衡障害などの症状が短期間に変動する。C 軽度から高度までさまざまな異常所見を認める。D難聴は、変動性、進行性難 聴、再発性などの経過が診断の参考となる。Eめまいは浮動性で不定愁訴を思わせることが多い。

われわれは平成24年からエライザ法を導入し、より特異度・感度を上げた検査を実施している。本報告では、CTP 検査 の生化学的信頼性にも焦点をあて、CTP の安定性、凍結融解テスト、夾雑物の影響に関するテスト、希釈再現性等に関し ても検討した。 